
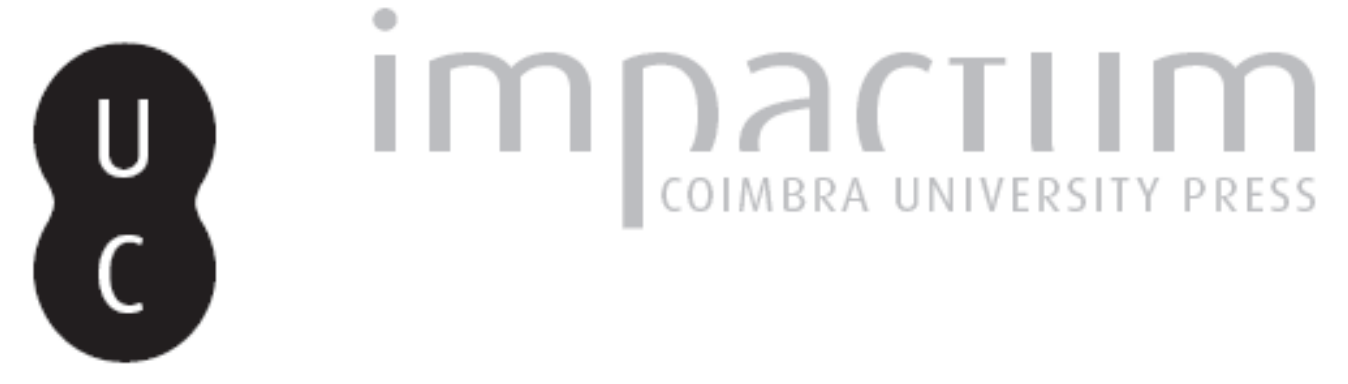

\title{
No. 110 10.4.93-10.7.93 or Polish uncreative writing
}

\section{Autor(es): Marecki, Piotr}

Publicado por: Centro de Literatura Portuguesa; Imprensa da Universidade de Coimbra

URL persistente:

URI:http://hdl.handle.net/10316.2/39100

DOI:

DOI:http://dx.doi.org/10.14195/2182-8830_4-2_6

Accessed : $\quad$ 26-Apr-2023 12:23:20

A navegação consulta e descarregamento dos títulos inseridos nas Bibliotecas Digitais UC Digitalis, UC Pombalina e UC Impactum, pressupõem a aceitação plena e sem reservas dos Termos e Condições de Uso destas Bibliotecas Digitais, disponíveis em https://digitalis.uc.pt/pt-pt/termos.

Conforme exposto nos referidos Termos e Condições de Uso, o descarregamento de títulos de acesso restrito requer uma licença válida de autorização devendo o utilizador aceder ao(s) documento(s) a partir de um endereço de IP da instituição detentora da supramencionada licença.

Ao utilizador é apenas permitido o descarregamento para uso pessoal, pelo que o emprego do(s) título(s) descarregado(s) para outro fim, designadamente comercial, carece de autorização do respetivo autor ou editor da obra.

Na medida em que todas as obras da UC Digitalis se encontram protegidas pelo Código do Direito de Autor e Direitos Conexos e demais legislação aplicável, toda a cópia, parcial ou total, deste documento, nos casos em que é legalmente admitida, deverá conter ou fazer-se acompanhar por este aviso.

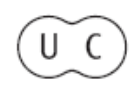



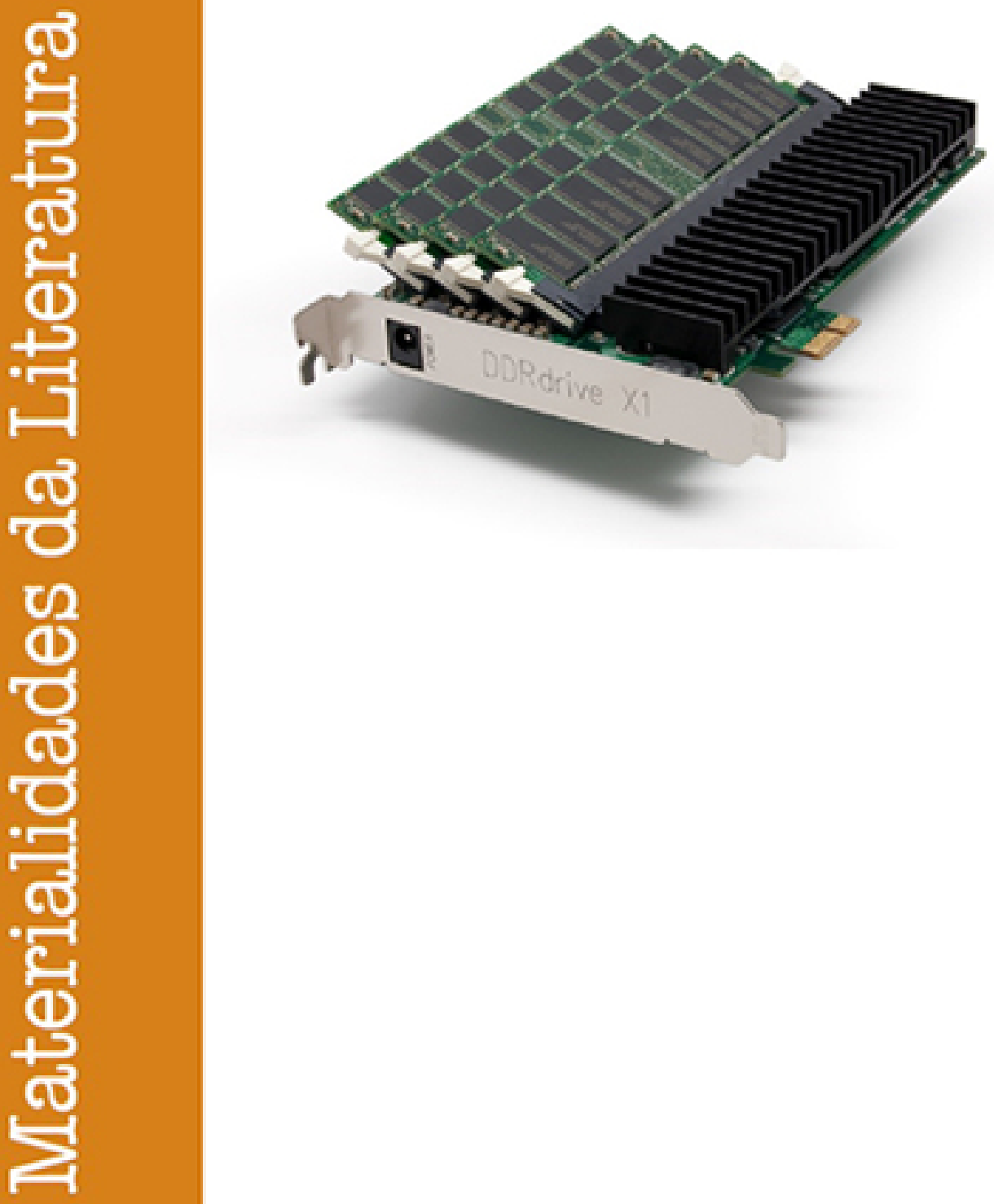

Vol. 4.2 (2016) ISSN 2182-8830

'Estudos Literários Digitais 2'

Manuel Portela e António Rito Silva (orgs.) 


\title{
No. 110 10.4.93-10.7.93 or Polish Uncreative Writing PIOTR MARECKI \\ Jagiellonian University
}

\begin{abstract}
This article provides an overview of Polish digital literature, using the tools and vocabulary of uncreative writing put forward by American artist and theorist Kenneth Goldsmith. The analysis covers appropriation techniques, plagiarism types, and the thinkership of conceptual writing practices. The selected works use various media and explore diverse textual materialities, which depend on specific platforms, such as the MERA 300 minicomputer, the Wikipedia platform, or JavaScript. The pieces are described in terms of database studies in contemporary digital literature. Keywords: uncreative writing; conceptual writing; digital literature; Kenneth Goldsmith; appropriation.
\end{abstract}

Resumo

Este artigo apresenta uma visão geral da literatura digital polaca, recorrendo às ferramentas e ao vocabulário da escrita descriativa ["uncreative writing”] apresentada pelo artista e teórico americano Kenneth Goldsmith. A análise aborda técnicas de apropriação e tipos de plágio, assim como os mecanismos de pensamento das práticas de escrita concetual. As obras escolhidas usam diversos meios e materialidades textuais, dependentes de plataformas específicas, tais como o minicomputador MERA 300, a plataforma Wikipedia, ou JavaScript. As obras são descritas segundo a perspectiva dos estudos de base de dados na literatura digital contemporânea. Palavras-chave: escrita descriativa; escrita concetual; literatura digital; Kenneth Goldsmith; apropriação.

No. 110 10.4.93-10.7.93

$\mathbf{N}$ o. 110 10.4.93-10.7.93 should be acknowledged to be the cornerstone of Polish uncreative writing; it was published in chapbook form by the most influential experimental literary author using appropriation techniques-Kenneth Goldsmith. In 1993 the American artist was invited to the "Construction in Process" Festival in Lódź, where he decided to stage an experiment in writing something in the Polish language, not knowing a single word of the language and never having used Polish to speak or write. In the statement accompanying the publication Goldsmith recalls that the majority of Americans are monolingual. This shows itself in the great sense of the hegemony of the English language. He stressed that the last thing an American text-based artist could bring to a country like Poland was a work in the English language. Goldsmith stated that he was coming from a standpoint of "willful ignorance"; nonetheless, he undertook a work 
in a language he wanted to appreciate only through its sound. He described his method as follows: 'it allows me to 'sight' language by stringing together words according to their audio and/or phonetic combinations" (1993: 1).

The point of departure for Goldsmith's project involved gathering Polish newspapers, magazines, and pornography, and exploring these materials to find words, sentences, and expressions for a literary work. The project then developed, and Goldsmith gathered students working on a museum exhibition, who added phrases, sentences, and individual words to the collection. On the first day the Poles began with off-the-cuff statements, then moved on to expressing their relationships to the government, the pope, politics, solidarity etc. On the final day the statements largely became quite personal. As the author suggested in the title, the group process of collecting a textual database for the work continued from October $4^{\text {th }}$ to $7^{\text {th }} 1993$.

The result of the experiment was a work containing 1,500 words in the Polish language, of which the author understood nothing. Based on these notes Goldsmith gave the work its final shape. He adopted the following principle: "I put the words and phrases into an alphabetic and syllabic order with the entries going from one syllable $A$ to $Z$, then a semi-colon, then two syllables A to Z, then a semi-colon, then three syllables A to Z, etc., all the way up to 40 or 50 syllables" (1993: 1$)$.

In these final words detailing the work's construction, Goldsmith raises a most important issue, and one that would become decisive in the birth of the uncreative writing movement and the factors that have caused a flood of such writing in the digital age-above all the changes in approach to authorship and copyright laws in their broadest definition. This is one of Goldsmith's first works (many bibliographies list it as his first text published in chapbook form) and a forerunner of the plagiarism strategies of which Goldsmith would later become a fierce proponent, and which came to occupy a regular place in his work. Teamwork and its effect on writing techniques in the digital age are a separate issue. Goldsmith even boasts that the people who donated words felt like co-authors of the piece. In an era of widespread textual remixing and creative commons the author stresses that he created a mutual ownership work, perhaps without an author or a proprietor. The process in which the work was created can thus be seen in terms of social categories (collective authorship, expression of the group of people who speak a particular language at a particular time). 
a, azazazaazahhhhhhhhhhh!, ah, ba, bah, bla, cpa, cza, da, dla, dnia, ta, gra, ha! ha, ja, Jah, kra, ma, na, pa, sra, za; A-Ha, a ha, Abba, Albh, Ania, Anka, aura, banis, ben-wa. Buddha, cena, chutzpuh, cipa. Dada, dawna, dharma. Diva, dobra, droga. ducha, dwiema, działa, fatwa, folia, gaga, gietda, haha, hasta, huja, Ina, Inka, Ira, jaja. jajka, Karma. Kasia. Khmer, książa, która, kurma, Layla, Lekcja, linia, lufa. Lycra. Magda, mama, Mazda, Meca, można, NASA, nasza. Ninja, nowa, padta. panstwa, piwa, pizda, poczta, Polka, poza, praca, prosta, ptaszka, Rasta, reszta. rocker, ropa, Rosja, serca, shiksa, smacznie, sprawia, sraka, syna, szkoda, słowa. taka, Tantra, tata, Thriller, Torah, Tosea, trawa, trze ba, Visa, visa, Wajda walka. ważna, Wódka, zodrowia, życia: Aktorka, Aldona, Anarchia, Aneta, Ayatollah. badania, Bar Mizzah, bla bla bla. Bonanza, cios Ryska, druciara, Dynastia, Frank Zappa, Franz Kafka, fryzura, Jane Fonda, kierowca, Klub Szafa, Kojaka, koncepcja, Konstrukcja, lewica, Lypsinka, Madonna, Mamusia, Mazepa, Metallica, Moc lustra naraża. Nirvana, odległa pamięta, Paul Anka, pieniąza. Piotrkowska. Polaka, poleza, posoka, powstak, pozycja, Potczytiska, prawica, promocja, przeznacza, pytania, rozbicia, różnica, ryzyka. Siegenia, Spotecana, szcypowika, tendencja, tra-b-ka. Treblinka, ulega, Uwaga!, Vesulka, warba, Warszawa, Wesolka, wrgoda, zapewnia; atak Wiodka, bezrobocia, ciagnat druta, co nam obca, Coca Cola, Czy zabika?, czyja "Kasia?", Dabi Lama, do kosciota, do lizanib. do wyssania. Dobranocka, Documenta, francowata, Frank Sinatra, Fred i Wilma, głupia dziwka, Halo Dwojka, huj tatusia, impotencja, Innowacja, Ja artystika, jajka burka. Jest fundacja. Adra mob. Ken do kibla, koalicja. Lech Walesa. Mama i ja. marihuana, matka boska, moja pata, mowa trawa. Multi Vita, Nasza sonda, nerwus siusia. Peina chata. Pokolenia. Polsia zbrojna prezydenta, producenta, prostytucja, przemoc wzieła, pyta księda, qfel twwa rewolucja, Sigmar Polke. stanowiska, strugat glupa, Sztyma kasa, szukam chłopa, teraz Polska, walac konia. Wieczorynka, wojewoda, woskowina wykazania, zacofania, zapiąc buta, zapowiada, zupa z trupa: abrakadabra. Ala ma kota. Andy Warhola chee dinozaura, czerwono-biata, dobra zabawa, dzisiaj blokada, filmy z talera. Goraca linia. Hanna Suchocka, hasta levista, hiperinflacja, igraszika paszzka, Jerozolima, Jerry Kosseb. Justusa Frantza, kasza tukasza, kochana moja. Krwawa niedziela. Legia Warszawa. Maria Skłodowska, Marta Lipinska, mikosć jest złudna. NATO

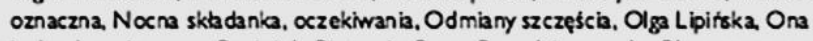
a kocha, pieprzmy Papieza!. Piotrusia Pana. Prawdziwe cuda. Ptonace serca. Róbta co chceta, rozkosz anal na, ruchliwe biodra, Rzeczpospolita, sekrety szczescib. scty do spania. Supermodelka, sztuka jest sztuka, tele nowela. To jest nagroda!. Trzecia granica, ulica Tylna. W Moskwie - rewolta. Winona Ryder. Woody i Mia, wassata gẹba: 4 pażdziernika, 16.00 Program dnia, Ale mi siẹ pic chce. Anna Białobroda. Art In America. Bezskuteczine prawda? bog honor "Ojczyna", całonocna orgia, cheiala to dostała, chłopiec do kochania, cycata blondynka, Do trzech razy sztuka. Europa Europa, faceci do pieca!. Kawa czy herbata?. Kino konesera, Lepsza of Bagsika. Michaela jacksona. Miejsce urodzenia, Muzyczna Jedynka, mysz ergonomiczna. Nie dla psa kielbasa, niezta zawodniczika, Ojczyzna-polszczyzna, ostatnia szansa, Paulina Porizkova, Pechowa .Dziewiqtka", Pijana Danuta, polka polka polka!!!, praktyczna higiena, Prastanck Alaska, Sportowa sobota, Sztuka uwodzenia, ta moskiewska wojna,

Figure 1.

With conceptual art the reading of the work is less important than the thinkership level it sets in motion. For the Polish reader this work holds double significance. On the one hand it is a stream of collective consciousness expressed through an author who can be treated as a medium that does not understand it. The date of creation, which is also the title of the work, evokes and highlights the post-transformation period; the collective author lists many names of politicians who were later forgotten, alternating with film stars or celebrities of the era. The Poles enlisted by Goldsmith also expressed 
their opinions on politicians, and many phrases were also drawn from the media that emerged after the transformation, such as Gazeta Wyborcza. Significantly, the word "communism" does not appear once, although the work was written only four years after the system collapsed in Poland; even so, there are many voices which express the oppressiveness of the church, such as "Screw the Pope!" And although the American author did not design his work as such, in our day it can be seen as to reflect the collective obsessions following the political transformation, and to communicate something about identity in the Polish universe.

There is another way in which the work might be seen as anticipating critical strategies against the dominance of the English language in the field of literary experimentation. The decision to write in the Polish language is an affirmation of the peripheral, and works as a decentering strategy. Goldsmith's gesture might be seen as seizing or appropriating the language and collapsing the line between the dominant and the dominated.

Uncreative strategies in contemporary literature often result from an awareness of platforms and media; selected works based on uncreative strategies are often physically excerpted or taken from original works, upon which the secondary works are based. This tactic results from the use of text editors and processing where cut-and-paste functions have become part of the writer's craft. Goldsmith writes: "When cutting and pasting are integral to the writing process, it would be mad to imagine that writers wouldn't exploit these functions in extremer ways that weren't intended by their creators" (2011: 5).

Goldsmith saw the Polish language as a database, from which he drew components that fit his concept of the work according to his own principles. As such, his work falls in line with a leading tendency in the digital era: replacing narrative with databases. And although the American author's work was created in an analogue fashion, we cannot deny the similarity to digital text generators, which randomly pick words, sentences, or larger constructions from selected initial data. This approach to language as a database for performing textual operations became a characteristic of the great majority of works labeled uncreative writing-as well as for the works covered in this article.

It is believed that the methods and tools Goldsmith describes are ideally suited for reading the writer's own works. In this sense, the theory was to accompany the work, a way of thinking that suits the model of avant-garde artists who append theoretical reflections to their works. The present article seeks to upend this way of thinking and to apply Goldsmith's methodology to reading Polish literature. The foregoing aspects of the uncreative projects created in the Polish language, as well as the changes in the copyright situation and the use of platforms, will be given special attention in this article. 


\section{Uncreative Writing}

Uncreative writing is a technique of writing which employs strategies of appropriation, replication, piracy, plagiarism, DJing and sampling. The term was put forward by Kenneth Goldsmith in his book Uncreative Writing: Managing Language in the Digital Age. Goldsmith not only approves of the term and writes with its principles in mind, he also teaches a course with this title at the University of Pennsylvania. The term uncreative writing references popular creative writing workshops, but, in a subversive way, tries to include techniques from new media and critique the traditional concept of "creativity."

Uncreative techniques are born through the vastness of texts, databases, and information used in digital communities. Goldsmith notes: "These writers are language hoarders: their projects are epic, mirroring the gargantuan scale of textuality on the Internet." (2011: 4) These dimensions engender a particular approach to text and the use of certain genres and devices (such as enumeration). With such large quantities of text, practices that cannot be called literary are both understandable and aesthetically appropriate:

This joy is evident in the writing itself, in which there are moments of unanticipated beauty — some grammatical, others structural, many philosophical: the wonderful rhythms of repetition, the spectacle of the mundane reframed as literature, a reorientation to the poetics of time, and fresh perspectives on readerliness, but to name a few. (4)

Moreover, the discussion of uncreative writing incorporates issues of copyright in the digital age, as well as of gift economy. Precursors for the genre's techniques include artists such as Walter Benjamin, Gertrude Stein, James Joyce, and Andy Warhol. Kenneth Goldsmith argues that humanities, art and literature are based on a rich history of forgery, frauds, hoaxes, avatars, and impersonations. In addition, it is often said that the $21^{\text {st }}$ century is the heyday of piracy, DJing, sampling, copying, and editing. Thus, in today's literature and literary techniques, there is no shortage of new phenomena and genres, such as "hoax-poetry," avant-pop, code poetry, flarf, wiki-writing, found poetry (developed by writers who use Facebook), Twitter, Google, Gmail, Instagram, camera, and code. Goldsmith compares writers who use uncreative techniques to programmers rather than to traditional writers (2011: 4). Using someone else's texts can be justified through a kind of textual economy. By this premise, there are already too many texts, and new ones are no longer needed. It suffices to base our work on those already written or published, creating our own literary projects on their basis. 


\section{The Book of All Words}

Kenneth Goldsmith combines uncreative practices with digital media. The new opportunity to generate corpora of texts and files from ready-made databases has automatically prompted such tendencies. Creativity in the sense of "originality" comes into play when making the code or writing the algorithm that will use the "ready-made" input.

Polish digital literature begins with a work written in this vein. Acknowledged to be the first Polish digital literary text, The Book of All Words by Józef Żuk Piwkowski was created on a Polish MERA 300 minicomputer. The task it sets for itself is total-putting all the words in existence in a single book, including those that did not exist. The artist was the creator of a concept that led to the development of an algorithm (the actual creator of the algorithm was Mieczysław Gryglik). Żuk Piwkowski claimed no copyright for conceiving a work containing all words; he was, obviously, cognizant of other works created in a similar vein. Above all, he cites Borges as his inspiration to create this word-based digital work meant to imitate the concept of a 1:1 scale map. Another point of reference was the numbered paintings by Polish artist Roman Opałka, who painted digits, each in turn, in the Opałka $1965 / 1-\infty$ series. In this project running from 1965 to the end of his life, the artist managed to paint 5.5 million "details" (as the artist called the various pictures in the series). The totality of this conceptual work involved expressing the passing of time by recording it in the form of numbers.

The point of departure for the Book of All Words was the artist's work at the OBR MERA-POLTIK study/research institute in Lódź and his daily meetings with programmers. The office where Zuk Piwkowski was working had a Polish Mera-300 minicomputer the size of three present-day desktops. In the script describing the platform in the chapter on the system, the authors write: "MERA-300 minicomputers are small universal digital machines using 8-bit words, equipped with 8,16 , or $32 \mathrm{~K}$ word operating capacities. The central unit has a very simple construction based on two 8-bit rails of information and one battery record. There are thirty-four arithmetic (adding), logic, and steering commands in the list" (Misiurewicz and Rydzewski, 1979: 9).

Żuk Piwkowski states that his work with machines was not the result of waging a revolution. He used the tools and new technologies to carry out work that would not have otherwise been possible. The artist explains as follows:

I mean, we have a stylus and a tablet, but we write as though we had a pencil and paper, or we have Photoshop tools, but in fact we use a brush. I was not interested in this on principle, I thought: "it's like using a computer to plow a field." We can do it, but why should we? I was looking for ways to use this tool that would create a product that was not otherwise attainable. That's all. In a nutshell, we might say that The Book of All Words is a program (...) to which you can input data and count 
manually; you could use a piece of paper instead of a computer to get the same result, except that it would take, I don't know... hours, years, months, maybe decades. The computer counts them instantaneously. And it was mainly this aspect that fascinated me, and to this day I am attracted by finding ways of using a new tool, particularly in art, in media or creative tasks, that would be impossible otherwise." (Marecki, 2014: 100; my translation)

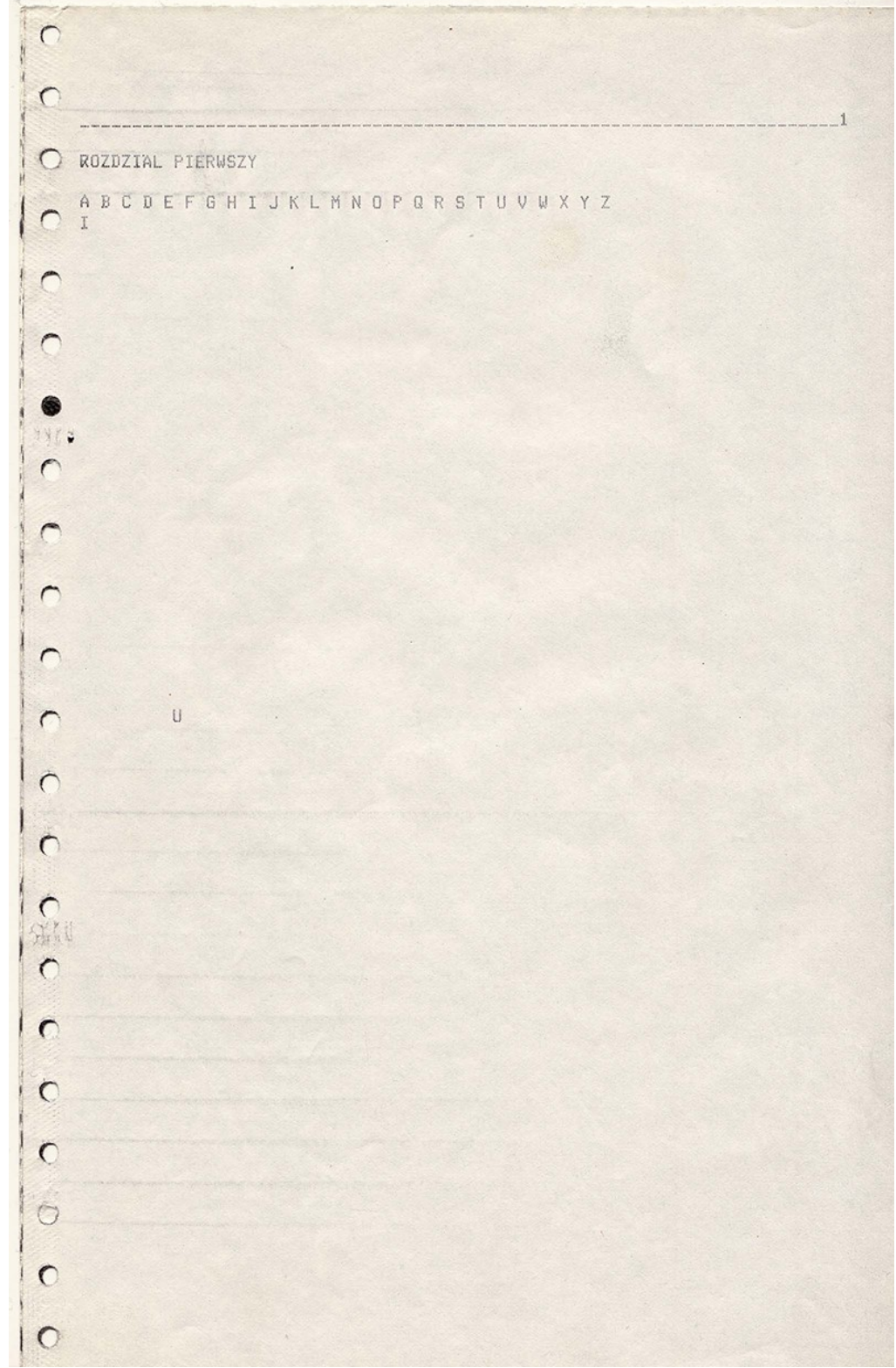

Figure 2 . 
D SZTTVE SZTTUF SZTTUG SZTTUH SZTTUI SZTTUJ SZTTUK SZTIVL SLIIUM SLII UN SZTTUO SZTTUP SZTTUQ SZTTUR SZTTUS SZTTUT SZTTUU SZITUV SLIIUW SLI TUX SZTTUY SZTTUZ SZTTWA SZTTWE SZTTWC SZTTWD SZTTWE SLIIWF SLIIWIS SL TTWH SZTTWY SZTTWJ SZTTWK SZTTWL SZTYWM SZTTWN SZTTWO SLIIWP SLIIWU S ZTTWR SZTTWS SZTTWT SZTTWU SZTTWU SZTTWW SZTTWX SZTTWY SLIIWL SLIIXA SZTTXE SZTTXC SZTTXD SZTTXE SZTTXF SZTTXG SZTTXH SZTTXI SZTTXJ SLIIXK SZTTXL SZTTXM SZTTXN SZTTXO SZTTXF SZTTXR SZTTXR SZTTXS SZTTXT SLIIX U SZTTXV SZTTXW SZTTXX SZTTXY SZTTXZ SZTTYA SZTTYB SZTTYC SLIIYU SLII YE SZTTYF SZYTYG SZTTYH SZYTYI SZTTYJ SZTTYK SZTYYL SZTTYM SZIIYN SZI TYO SZTTYP SZTTYQ SZTTYK SZTTYS SZTTYT SZTTYU SZTYYU SZIIYW SLIIYX SL TTYY SZTTYZ SZTTZA SZTTZB SZTTZC SZTTZD SZTTZE SZTTZF SLIILU SLIILH S ZTTZI SZTTZJ SZTTZK SZTTZL SZTTZM SZTTZN SZTTZO SZTTZF SZTTZU SLIILR SZTYZS SZTTZT SZTTZU SZTTZU SZTTZW SZTTZX SZTTZY SZTTZZ SLIUAA SLIUAB SZTUAC SZTUAD SZTUAE SZTUAF SZTUAG SZTUAH SZTUAI SZTUAJ SLIUAK SLIUA L SZTUAM SZTUAN SZTUAO SZTUAF SZTUAQ SZTUAR SZTUAS SZIUAI SLIUAU SLIU AU SZTUAW SZTUAX SZTUAY SZTUAZ SZTUBA SZTUBB SZTUBL SLIUBII SLIUBE $\$ \angle I$ UBF SZTUEG SZTUBH SZTUBI SZTUBJ SZTUBK SZTUBL SZTUBM SLIUEN SLIUEU SL TUEF SZTUBQ SZTUER SZTUES SZTUET SZTUEU SZTUBV SZTUBW SLIUEX SLIUBY S ZTUBZ SZTUCA SZTUCB SZTUCC SZTUCD SZTUCE SZTUCF SZTUCG SZTULH SLIUL1 SZTUCJ SZTUCK SZTUCL SZTUCM SZTUCN SZTUCO SZTUCF SZTUCQ SLIULK SLIULS SZTUCT SZTUCU SZTUCU SZTUCW SZTUCX SZTUCY SZTUCZ SZTUDA SZIUUE SLIUU C SZTUDI SZTUME SZTUDF SZTUMG SZTUAH SZTUUI SZTUDJ SLIUUK SLIULL SLIU DM SZTUON SZTUDO SZTUDF SZTUDQ SZTUDR SZTUDS SZIUUI SLIUUU SLIUIU SLI UDW SZTUDX SZTUNY SZTUDZ SZTUEA SZTUEB SZTUEC SZTUEII SZTUEE SLIUt S SL TUEG SZTUEH SZTUEI SZTUEJ SZTUEK SZTUEL SZTUEM SZTUEN SZTULU SLIUEF' S ZTUEQ SZTUER SZTUES SZTUEY SZTUEU SZTUEV SZTUEW SZTUEX SZTUEY SZIULL

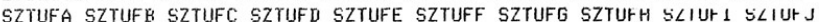
SZTUFK SZTUFL. SZTUFM SZTUFN SZTUFO SZTUFF SZTUFQ SZTURK $\$ \angle I U T S ~ S \angle I U H$ T SZTUFU SZTUFU SZTUFW SZTUFX SZTUFY SZTUFZ SZTUGA SLIULE SLIULL SLIU GII SZYUGE SZTUGF SZTUGG SZTUGH SZTUGI SZTUGJ SZTUGK SLIULIL SLIULIM SLI UGN SZTUGO SZTUGP SZTUGQ SZTUGR SZTUGS SZTUGT SZTUGU SZTUGV SZTUGW SL TUGX SZTUGY SZTUGZ SZTUHA SZTUHB SZTUHC SZTUHD SZTUHE SZIUHF SLIUHIS S ZTUHH SZTUHI SZTUHJ SZTUHK SZTUHL SZTUHM SZTUHN SZTUHO SLIUHY SZIUHU SZTUHR SZTUHS SZTUHT SZTUHU SZTUHU SZTUHW SZTUHX SZTUHY SLIUHL SLIUIA SZTUIE SZTUIC SZTUIA SZTUIE SZTUIF SZTUIG SZTUIH SZTUII SLIUIJ SLIUI K SZTUIL SZTUIM SZTUIN SZTUIO SZTUIP SZTUIQ SZTUIR SZTUIS SLIUII SLIU IU SZTUIU SZTUIW SZTUIX SZTUIY SZTUIZ SZTUJA SZTUJB SZTUJC SZTUJD SLI UJE SZTUJF SZTUJG SZTUJH SZYUJI SZTUJJ SZTUJK SZTUJL SZTUJM SLIUJN SL YUJO SZTUJF SZTUJQ SZTUJK SZTUJS SZTUJT SZTUJU SZTUJU SLIUJW SLIUJX S ZTUJY SZTUJZ SZTUKA SZTUKE SZTUKC SZTUKI SZTUKE SZTUKF SLIUKL SLIUKH SZTUKI SZTUKJ SZTUKK SZTUKL SZTUKM SZTUKN SZTUKO SZIUKF SLIUKLE SLIUKR SZTUKS SZTUKT SZTUKU SZTUKU SZTUKW SZTUKX SZTUKY SZTUKL SLIUL.A SLIUL B SZTULC SZTULI SZTULE SZTULF SZTULG SZTULH SZTULI SZTULJ SZIULK SLIU LL SZTULM SZTULN SZTULO SZTULF SZTULG SZTULR SZTULS SZTULI SLIULU SLI ULU SZTULW SZTULX SZTULY SZTULZ SZTUMA SZYUME SZTUMC SZTUML SLTUME SL TUMF SZTUMG SZTUMH SZTUMI SZTUMJ SZTUMK SZTUML SZTUMM SLIUMN SLIUMU S ZTUMF' SZTUMQ SZTUMF SZTUMS SZTUMT SZTUMU SZTUMU SZTUMW SLIUMX SZIUMY SZTUMZ SZTUNA SZTUNB SZTUNC SZTUNA SZTUNE SZTUNF SZTUNG SZIUNH SLIUNI SZTUNJ SZTUNK SZTUNL SZTUNM SZTUNN SZTUNO SZTUNF SZTUNR SZTUNR SZIUN S SZTUNT SZTUNU SZTUNU SZTUNW SZTUNX SZTUNY SZTUNZ SZTUUA SLIUUB SLIU OC SZTUON SZTUOE SZTUOF SZTUOG SZTUOH SZTUOI SZTUOJ SZTUOK SZTUUL SLI OC SZTUOD SZTUOE SZTUOF SZIUOG SZTUOH SZTUOI SZTUOJ SZTUOK SZTUUL SL YUOW SZTUOX SZTUOY SZTUOZ SZTUF'A SZTUFB SZTUPC SZTUPL SLIUP' SLIUP' S ZTUF' SZTUF'H SZTUFI SZTUFJ SZTUF'K SZTUPL SZTUPM SZTUF'N SZIUP'U SLIUP'F SZTUFO SZTUFF SZTUFS SZTUPT SZTUFU SZTUFU SZTUFW SZTUPX SZTUPY SZIUPZ SZTUPO SZTUPK SZTUPS SZTUPT SZTUPU SZTUPU SZTUPH SZTUPX SZTUPY SZIUPZ SZTURA SZTURE SZTURC SZTUQD SZTUQE SZTUAF SZTUQG SZTUQH SZTUQI SLIUL J SZTUQK SZTUQL SZTUQM SZTUQN SZTUQO SZTUQF SZTUQQ SZTUQR SLIUUS SLIU QT SZTUQU SZTUQN SZTUQW SZTURX SZTUQY SZTUQZ SZTURA SZIUR'B SLIURL SLI URO SZTURE SZTURF SZTUFG SZTURH SZTURI SZTURJ SZTURK SLIUKL SZTUKM SL TUFN SZTURO SZTURP SZTURQ SZTURR SZTURS SZTURT SZTURU SZTURV SZIUKW S

Figure 3.

The Book of All Words is thus made of an algorithm which prints pages of a conceptual Book of the artist's design. The program assigns a word to a chapter or page of this Book. As such, the program requires a user to give the machine the task of generating pages from existing (or non-existing) words in 
a given language. The input data is all the letters of the Latin alphabet; the program has no diacritical marks. Uncreativity is achieved through the algorithm processed by the computer, which counts and prints the pages. The user sets the generator in motion; he/she may or may not be the artist or creator of the idea.

This work was made in the 1970s, but was ported to HTML and transferred online when the Internet became widely available. From then on, the user could write a word in a search engine and get The Book of All Words as output. This remote user model was tested by the artist in the 1980s, when three institutions in Poland, France (Centre Georges Pompidou), and the USA (MIT) were meant to conduct long-distance experiments, using telephone connections.

The artist described this project as follows:

What these works had in common was the fact that they did not physically exist, and one of them, the simplest one, was print-outs from The Book of All Words. In order to print out a page as a souvenir, a person had to supply a word and its definition. In other words, someone in Paris could supply a word and a definition, and someone else in New York could receive the work, and the same occurred in Lódź or in Boston. There was a range of related ideas, there was a work that involved scanning, another that assembled a text, i.e. that built a book... the sort of thing that later emerged in blogs; bloggers create a chain of authors. All that was well and good, everyone was delighted, I was delighted that they wanted to take part, but it all collapsed through the simplest link in the chain -in Poland telephone contact was established through telephone operators back then. I had the codes and passwords to the computer at MIT, and I had access to a computer in a military center in Warsaw that was willing to collaborate. No doubt they wanted access to the computer at MIT (laughs). This obviously required telephone contact, and unfortunately we couldn't get through the operators. I drove out to the Bemowo district to an institution and sat there for hours, they gave it their best, but we couldn't make contact" (Marecki, 2014: 102; my translation).

Although Żuk Piwkowski's piece is a highly computational work, in the MERA computer version selected pages were printed out after the program was read from the tape. In the online version the work was remediated, the pages are generated in a digital version, although these can also be printed out. 


\section{Jarostaw Lipszyc: A strategy of Mnemotechniques ${ }^{1}$}

Jarosław Lipszyc, a poet and social activist, said in an interview on his 2008 volume:

I adopted the rule that I would not even write one letter myself in Mnemotechniki [Mnemotechniques]. I have succeeded. The texts I used come from an Internet encyclopedia called Wikipedia. All of the work was done through typing keys: "copy," "paste," "save." By colliding fragments of encyclopedic entries, I tried to tell my own story (Zaleska, 2008).

Lipszyc is the author of three poetry books, bólion w kostce (1997), poczytalnia (2000), and Mnemotechniki (2003), the co-author of The Neolinguistic Manifesto (2003), and the chairman of The Modern Poland Foundation, which is responsible for the Wolne Lektury [Free Literature] Internet project. He promotes Creative Commons, supports free access to culture, and organizes Public Domain Day. He was the poet of choice during protests against ACTA; at that time he often appeared in the media and spoke about copyright issues. ${ }^{2} \mathrm{He}$ is active in freeing literature, and also supports this attitude with his texts; Mnemotechniki was published in traditional form as well as on the Internet, in Wikisource (Lipszyc, 2008), which means that any reader can freely change, copy, and distribute the contents. Apart from the poems, the book includes a list of authors. In a few pages, hundreds of names, nicks, bots, IP addresses, and automatons are listed. Another unusual element of the volume was the (twenty-page) addition of the GNU license under which the book was published, allowing for a legal departure from copyright laws. And, though the collages, remixes, and centos are nothing new in the history of literature, Jarosław Lipszyc's project was innovative in that it appropriated finished materials which were not under copyright. One could say that Wikipedia is a project which constantly develops and changes, and that the concept of an entry's author is debatable. Therefore, the idea of authorship of the text by the poet, who calls himself an "editor" on the cover, is even more indistinct and problematic.

The public composition of poetry is a slap in the face to the reigning idea of poetic inspiration. Many of Lipszyc's works were created as follows: during a meeting with an audience, the "author" chose two entries from the free

1 The portion of the text devoted to Jarosław Lipszyc appeared in Polish (in an altered version) as "Subversive Strategies in Polish Literature of the 20th Century," which appeared in Teksty Drugie, No. 6 (2012): 313-324.

2 On January 23 2012, Jarosław Lipszyc was a guest on a popular Polish TV program Corta Polska?

http://www.tvp.pl/vod/audycje/publicystyka/tomasz-lisnazywo/wideo/23012012/6098539 (24 Aug 2015). 
encyclopedia and mixed the texts. This resulted in a poem. He acted like a true MC, creating something new from ready-made materials, live in front of the audience (a DJ technique). This was a conscious action, as Lipszyc emphasized:

There are no artists creating ex nihilo, this is the damned legacy of Romanticism, which makes my blood boil. The Romantic vision of an artist who, under divine inspiration, creates something from nothing, guided by inspiration alone. This vision is the foundation of today's copyright law. But this vision is far from reality, where most creations are built upon some kind of groundwork (Dunin-Wąsowicz, 2008: 10).

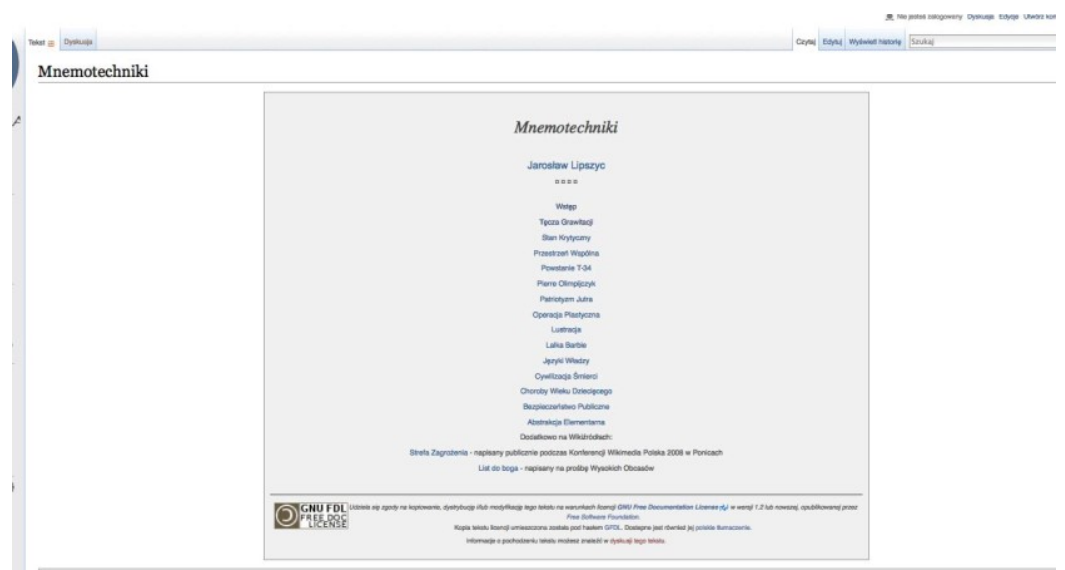

Figure 4.

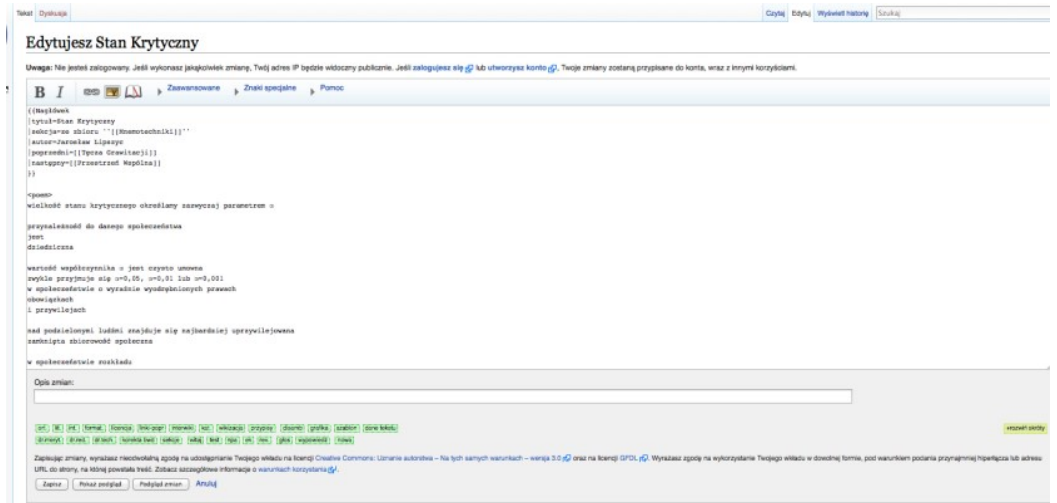

Figure 5.

The subversiveness of Lipszyc's attitude, technique, and gesture is focused on a struggle against the copyright laws that hold away in the book market and literature, which restricts the authors' freedom. Apart from the literary-theory slogans used by the poet ["I am not talking, the words are 
talking through me" (Dunin-Wassowicz, 2008: 13)], Lipszyc's gesture was a radical manifesto on copyright, which remains intact despite a diametrically changing market situation (Internet publishing, copying, illegal distribution). In one interview, the poet said that after the publication of the volume he would continue working for freedom, extending it within the frame of the law. As he emphasized:

Digital culture works only because nobody abides by those absurd prohibitions. If we tried to follow them, culture would get bogged down, authors would rebel, we would need a radical change of the system, in which the proxies only execute their right when it is convenient to them. The copyright situation is such that we have a law which only works when it is broken. Creative freedoms can only be respected by breaking this law. This is a corrupt and pathological situation (Dunin-Wasowicz, 2008: 11).

In this project, the author himself-traditionally seen as someone who produces an infallible creation - is only an "editor" remixing someone else's pre-made content. He adds nothing himself. He technologically processes the ready-made material, and, through GNU publication, he credits the reader with extended authorship rights in the process of adding, changing, and distributing the volume. As Lipszyc states: "The distinction between the recipient and the sender is an artificial one. We are all users of culture, machines with both input and output" (Dunin-Wąsowicz, 2008: 13).

As such, Lipszyc's project is a part of open-source culture in its broadest definition. When published online, however, it did not inspire mass remixes. One reason for this could be the editor function. Although it was created based on uncreative methods, the work required editorial control. It did not encourage users to play with the code itself, or the database. In Lipszyc's project, the stamp of the author continued to play a vital role.

\section{Thorny Diodes}

Another uncreative technique was applied by Leszek Onak, a poet, programmer, and creator of algorithms. In 2014, during the Ha!wangarda Media Art Show Festival in Krakow, he presented the Thormy Diodes generator, based on the work of Bruno Schulz. With this work, Onak joined the ranks of those who have appropriated Schulz's short stories. Schulz is a Polish writer who is considered a "powerful artist," whose work had already served to inspire many artists. David Goldfarb lists over a dozen names in world literature (including Jonathan Safran Foer and Philip Roth) who had cited Schulz as an inspiration. As Goldfarb suggests, the work of this artist, and the myth of his death in particular, provoke artists to create work based on loss and 
erasure. Among the most well-known and influential uncreative works has been Tree of Codes by Jonathan Safran Foer, who composed a new novel on the basis of the English translation of Street of Crocodiles, erasing a significant portion of the text. Foer's method involved physically cutting the text (Foer, 2011). With this gesture the writer drew from the myth of the book, which is central to Schulz's topos. In statements quoted by Goldfarb we find that Foer saw his novel as a new work that was nonetheless part of Schulz's myth of the Book. As such, although the American writer did not add a single word of his own, he created a new novel, inscribing it in the narrative of the text he appropriated.

For Polish writers, Schulz plays the part of the powerful artist. When Schulz's works entered the public domain, artists and programmers began making uncreative reworkings for their own artistic ends and pleasure. Apart from Onak's above-mentioned generator, there was also the Idolator textual game based on fragments of the short stories. As Mariusz Pisarski writes:

Onak thus shows that a classic author like Schulz is practically inexhaustible: there can be as many remixes, mediations, and adaptations as their potential authors (2014).

Onak's work is uncreative par excellence. Like the other authors covered in this article, the writer did not add a word of his own, he only drew from what already existed. The Thorny Diodes generator is based on the Dadaist notion of a pairing of two texts from various fields. Schulz's text, which Foer describes as being highly rich and metaphorical, is mixed with the operating instructions for the Fiat $125 \mathrm{p}$ automobile, which was popular during the People's Republic (Morawski, 1982). Onak's concept involves contaminating the surrealistic work with a practical handbook filled with tools, car parts, and components. The final effect is to reinvigorate a classic, inscribing it in a Futurist style convention. The output of the work is twenty-eight screens, interchanged by the command "Refresh the diodes." The work is programed in JavaScript, and the text is randomly drawn from two files, one of which is the excerpts from the manual (the file is called "Verbs_all.js," of which there are 156), and the other the whole of Schulz's short story (Text.js).

A sample excerpt of the Schulz input will thus look as follows, where all the excised fragments are nouns selected by Onak. The author of the algorithm marked the nouns in terms of singular or plural, type, and declination, for their substitution with nouns from the automobile handbook.

chapter[5] = "W sobotnie popołudnia wychodziłem z LP_N_Ż na LP_B_M. Z półmroku LP_D_Ż wstępowało się od razu w słoneczną kapiel LP_D_M. Przechodnie, brodząc w LP_Ms_N, mieli oczy zmrużone od LP_D_M, jakby zalepione LP_N_M, a podciagnięta górna LP_M_Ż odsłaniała im LM_B_NIE i LM_B_NIE. I wszyscy brodzący 
w tym dniu złocistym mieli ów grymas LP_D_M, jak gdyby LP_M_N nałożyło swym wyznawcom jedną $i$ tę samą maskę - złotą maskę LP_D_N; i wszyscy, którzy szli dziś ulicami, spotykali się, mijali, starcy i młodzi, dzieci i kobiety, pozdrawiali się w LP_Ms_N tą maską, namalowaną gruba, złotą LP_N_Ż na twarzy, szczerzyli do siebie ten grymas LP_D_M - barbarzyńską maskę LP_D_M.”;

chapter [5] = "On Saturday afternoons I used to go for [LP_a] with my [LP_x]. From the dusk of [LP_the], we stepped at once into the brightness of [LP_the]. The passers-by, bathed in melting [UP_x], had their eyes half closed against the glare, as if they were drenched with [UP_x]. Upper [LM_x] were drawn back, exposing [LM_the]. Everyone in this golden day wore that grimace of [UP_x]-as if [LP_the] had forced his worshippers to wear identical masks of [UP_x]. The old and the young, women and children, greeted each other with these masks, painted on their faces with thick gold [UP_x]; they smiled at each other's pagan [LM_x]-the barbaric smiles of [LP_x].”; (Onak, 2014)

The cut fragments are replaced with chunks from the database of 156 nouns, entered in all the declinations used by the Polish language:

verbs_all[3] = new Array(“m”, "LP”, “drążek kierowniczy”, "drążka kierowniczego", "draż̇kowi kierowniczemu”, "drążek kierowniczy", "drążkiem kierowniczym”, "drążku kierowniczym”, "drążku kierowniczym”, "LM”, “drążki kierownicze”, “drążków kierowniczych”, "drążkom kierowniczym”, "drążki kierownicze”, “drążkami kierowniczymi”, "drążkach kierowniczych", "drążki kierownicze”);

verbs_all[3] = new Array(“ct”, "m”, "steering rod”, "steering rods”, “a”); (Onak, 2014)

The generator thus selects a grammatical version from the lexicon, substitutes it, and spits out a kind of stain. It is not by chance that the author has called the algorithm the "Brunonator," which alludes both to Schulz's first name and to a pair of well-known Polish generators: Bluzgator [Stainer] and Bluzgator bis [Stainer Encore].

By way of output, the program generates one of twenty-eight text paragraphs:

W lipcu [wirnik] wyjeżdżał do [komór silnika] i zostawiał mnie z [korozja] i starszym [napędem] na pastwę białych od [smaru] i oszołamiających [zapłonów]. Wertowaliśmy, odurzeni [natężeniem prądu], w tej wielkiej [masie całkowitej] wakacji, której wszystkie [ciśnienia w ogumieniach] pałały od blasku i miały na [żeliwie] słodki do omdlenia miąższ złotych [sprężyn]. 
IN JULY my [rotor] went to take the [engine compartments] and left me, with my [corrosion] and elder [drive], a prey to the blinding white [grease] of the summer [ignitions]. Dizzy with [current intensity], we dipped into that enormous [total weight] of holidays, its [tyre pressures] blazing with [cast iron] and scented with the sweet melting pulp of golden [springs]. (Onak, 2014)

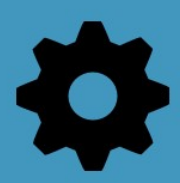

W lipcu cylinder pompy wyjeżdżat do warstw cyny i zostawiał mnie z magneśnicą i starszym cylindrem na pastwe białych od korektora hamowania i oszołamiajacych zaptonón. Wertowaliśmy, odurzeni gniazdem toziyska, w tej wielkiej korozij wakacji,

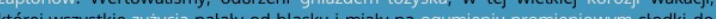
której wszystkie zuzycla pataty od blasku i miały na ogumieniu promieniowym stodki do omdlenia miąższ złotych dźwigni.

Figure 6.

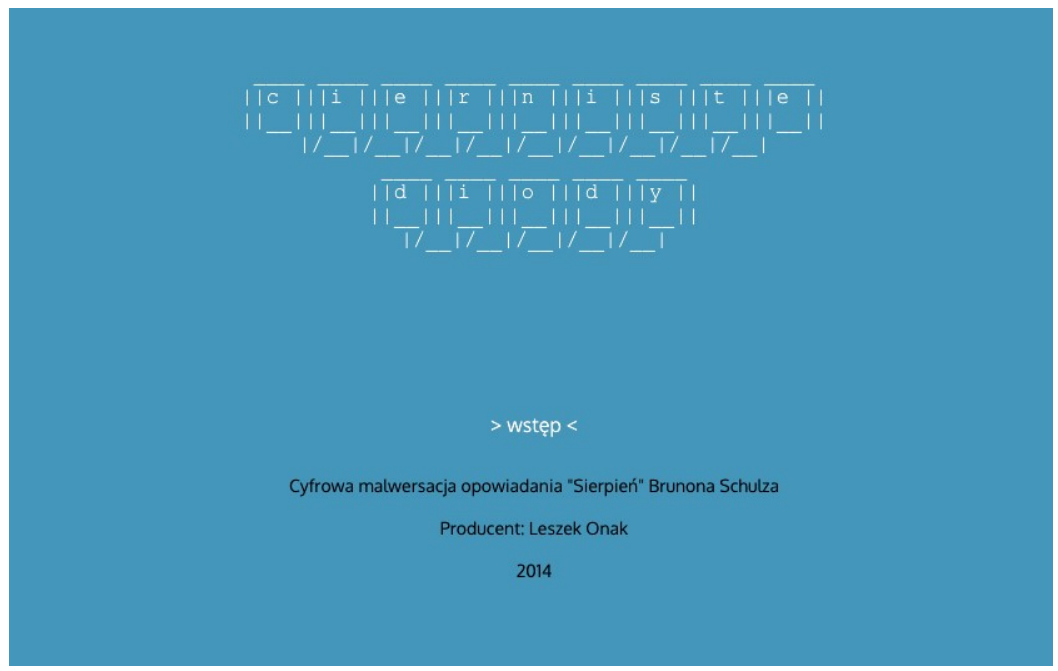

Figure 7. 
Onak's uncreative text can also be seen as coherent with the Schulzian topoi of lack and erasure. To this end the selected nouns from the short story "August" were removed, and these parts of the text are destroyed, soiled, stained - the author describes them as embezzled out - and replaced with recollections of a car which is not a source of much warm nostalgia in Poland.

Onak's gesture here inspired a remarkably original discussion on the limits of appropriation, chance, meaning in literature, and the very strategies of basing text on powerful authors. Artist Zenon Fajfer stood up for the meaning of Schulz's literature in his article "Thorny Idiotism," attacking Onak's embezzlement of Schulz. "You are the author of an exploit I can only describe as pure NIHILISM with a touch of STUPIDITY, or the other way around. And if this was a joke, it was in the worst taste" (2014). In the subsequent sections of his text, Fajfer made direct reference to Schulz's murder. As we have mentioned, Schulz's death has been a theme in the work of many authors. David Goldfarb describes the event in detail:

As a Jew with valuable artistic talents, Schulz had enjoyed the protection of a Nazi officer named Felix Landau, who employed him to paint murals for his children. During an anti-Jewish action known as 'Black Thursday' in Schulz's home town of Drohobycz on November 19, 1942, Landau allegedly shot a Jewish dentist who was protected by another Nazi officer named Karl Günther. The story, told by Izydor Friedman to Ficowski, is that Günther shot Schulz in revenge, with the line 'you shot my Jew; I shot your Jew'. (2011)

In Fajfer's heated attack against Onak, this moment was again evoked, and some very strong arguments were levied:

Maybe I do not have a sense of humor, but I received your stunt, or production (because I will not call it a "creation") and the cackle accompanying it on-scene as a kind of e-ssman-ic game of bullying the "Jewboy" (a kind of soft ss 2.0), as a reenacted e-xecution of Bruno Schulz. Your derisive commentary during the reading was especially disconcerting, since it revealed the true intentions behind the generation of this exploit (Fajfer, 2014). ${ }^{3}$

${ }^{3}$ This discussion on the limits of appropriation chronologically coincided with the discussion in the United States about Goldsmith's project in which he appropriated a report from Michael Brown's autopsy and presented it as his own work of poetry. Goldsmith's performance, organized at Brown University, lasted thirty minutes, and as reported by participants at the "Interrupt 3" conference, Goldsmith altered not a single word of the original version of the text. The result of this gesture was the creation of the anti-racist Mongrel Coalition Against Gringpo (http://gringpo.com), which acknowledged Goldsmith's gesture as racist (a white man employed at a university appropriated the text of a black man's autopsy). 


\section{Conclusion}

The above discussions on the limits of appropriation remind us of the emotions uncreative techniques are capable of stirring, and that this literature can be read as a form of expression. As Goldsmith has aptly noted, uncreative texts are based on a particular aesthetic, they have their readership, and are seen as fully-fledged literary works. These works also testify to changes in textuality in its broadest definition in the wake of the omnipresent digital media. Their authors create works for a variety of ends: to make serious conceptual works (Żuk Piwkowski), small algorithms written/programmed for fun (Onak), or works that aim to have a social impact, and to include literature in a wider discussion on changes in copyright law (Lipszyc).

There can be no doubt that the above-mentioned works can be called experimental or unconventional, breaking barriers and shifting boundaries in what we call literary expression. Moreover, Goldsmith's intuition concerning uncreative practices could be applied not only to this sort of literary production, but also to contemporary works that we define as mainstream literature, with large print runs and recognition from readers and critics. As recently as 2016, Polish reportage guru Mariusz Szczygieł-whose previous books had been on bestseller lists and were nominated for Poland's most important awards and translated into around twenty languages - decided to appropriate a work by deceased author Stanisław Stanuch in its entirely, alluding to it in later parts of his book (Szczygiel, 2016). In the instructions for this book, which was printed on two kinds of different paper (one for the "borrowed" text, the other for the original work), the reporter explains to the reader that he/she can skip over them, read them, or even physically tear them from the book.

Another approach to the issue of uncreativity in the mainstream comes from Wojciech Sumliński, a non-fiction author who made regular attacks on then-reigning Polish President Komorowski (Sumliński, 2015). His books asserted the politician's ties to the secret service and exposed the clan that consumed domestic political life, gaining him substantial popularity among those who supported the opposition. In January 2016 Newsweek reporter Jakub Korus (Korus, 2016) discredited this investigative reportage, showing that nearly thirty sections of the text were copied verbatim from other books (especially those fragments that were meant to build suspense and a conspiratorial atmosphere).

Uncreative strategies are also ubiquitous in many genres of Internet writing popularized through social media (e.g. Facebook). This platform in particular accumulates profiles, used to produce mainstream memes (the crowning glory of uncreative genres), which are then copied in television news programs, influential newspapers, or magazines, and which can function subversively, for instance, turning political speeches into forms of poetics. These mainstream adoptions of techniques described by Goldsmith deserve 
an article unto themselves. The greatest change takes place in the perception of the literary work in the digital age. Both the wholesale copying of another author's book and the text generator mixing instructions with masterpieces of literature are treated as literary genres, stages in the development of a national literature.

\section{References}

DUNIN-WĄSOWICZ, Paweł (2008). "Wojujący liberał. Jarosław Lipszyc rozmawia z redaktorem Lampy o swej walce o wolność twórczości artystycznej w granicach prawa autorskiego.” Lampa 6: 10.

GOLDFARB, David (2011). “Appropriations of Bruno Schulz.” Jewish Quarterly. 30 Jun. 2016. http://jewishquarterly.org/2011/06/appropriations-of-bruno-schulz/.

GOLDSMITH, Kenneth (1993). No. 110 10.4.93-10.7.93. Lódź: Artist Museum.

(2011). Uncreative Writing: Managing Language in the Digital Age. New York: Columbia University Press.

(2012). "Uncreative Writing." (course syllabus at the University of Pennsylvania). 30 Jun. 2016.

https://www.english.upenn.edu/courses/undergraduate/2012/fall/engl 111.301.

FAJFER, Zenon (2014). “Ciernisty idiotyzm.” Ha!art. 30 Jun 2016. http://www.ha.art.pl/projekty/felietony/4066-ciernisty-idiodyzm.

FOER, Jonathan Safran (2011). Tree of Codes. London: Visual Editions.

KORUS, Jakub (2016). "Idol prawicy Wojciech Sumliński pisząc o Komorowskim przepisywał... kryminały.” 30 Jun. 2016.

http://www.newsweek.pl/ksiazka-wojciecha-sumlinskiego-okomorowskim-to-plagiat-chandlera-i-macleana,artykuly,376871,1.html.

LIPSZYC, Jarosław (2008). Mnemotechniki. Wydawnictwo Krytyki Politycznej: Warsaw. 30 Jun. 2016. http://pl.wikisource.org/wiki/Mnemotechniki.

MANOVICH, Lev (2001). The Language of New Media. Cambridge, MA: MIT Press.

MARECKI, Piotr (2014). "Księga Słów Wszystkich, czyli archeologia mediów po polsku (wywiad)." Przeglad Kulturoznawczy 1.19: 98-105.

MISIUREWICZ, Piotr, and Andrzej Rydzewski (1979). Minikomputer MERA300. Instrukeja dla usytkownika. Warszawa: Wydawnictwa Politechniki Warszawskiej.

MORAWSKI, Edward (1982). Polski Fiat 125p—Budowa naprawa eksploatacja. Warszawa: Wydawnictwa Komunikacji i Łączności.

ONAK, Leszek (2014). “Cierniste diody.” Techsty. 30 Jun. 2016. http:// techsty.art.pl/cierniste_diody/.

PISARSKI, Mariusz (2014). "Tłoki, tuleje i Bruno Schulz. O Ciernistych diodach Leszka Onaka.” 30 Jun 2016. 
http://techsty.art.pl/aktualnosci/2014/cierniste_diody.html

—, and Marcin Bylak (2013). "Bałwochwał." Ha!art. 30 Jun. 2016. http://ha.art.pl/prezentacje/29-projekty/2817-mariusz-pisarski-marcinbylak-balwochwal-interaktywna-fikcja-sieciowa-na-podstawieopowiadan-brunona-schulza.html.

SUMLIŃSKI, Wojciech (2015). Niebezpieczne zwiqzki Bronisława Komorowskiego. Wojciech Sumlinski Reporter: Warsaw.

SZCZYGIEL, Mariusz (2016). Projekt: prawda. Warsaw: Dowody na Istnienie. ZALESKA, Zofia (2008). "Wywiad z Jarosławem Lipszycem." Gazeta Wyborcza. Stoteczna 27.5.

(C) 2016 Piotr Marecki.

Licensed under the Creative Commons Attribution-NoncommercialNo Derivative Works 4.0 International (CC BY-NC-ND 4.0). 